\title{
Economic potentiality of Colocasia esculenta L. under multipurpose tree- based agroforestry systems
}

\author{
Md. Hafiz All Amin 1,2, Sumaia Sumi1, Warangkana Jutidamrongphan ${ }^{3,4}$, Kua-anan Techato ${ }^{3,4^{*}}$ \\ ${ }^{1}$ Agroforestry and Environment, Faculty of Agriculture, Hajee Mohammad Danesh Science and Technology University, \\ Dinajpur-5200, Bangladesh \\ ${ }^{2}$ Sustainable Energy Management, Faculty of Environmental Management, Prince of Songkla University, Hat Yai, 90110, \\ Songkhla, Thailand \\ ${ }^{3}$ Environmental Assessment and Technology for Hazardous Waste Management Research Center, Faculty of \\ Environmental Management, Prince of Songkla University, Hat Yai, 90110, Songkhla, Thailand \\ ${ }^{4}$ Center of Excellence on Hazardous Substance Management (HSM), Bangkok 10330, Thailand
}

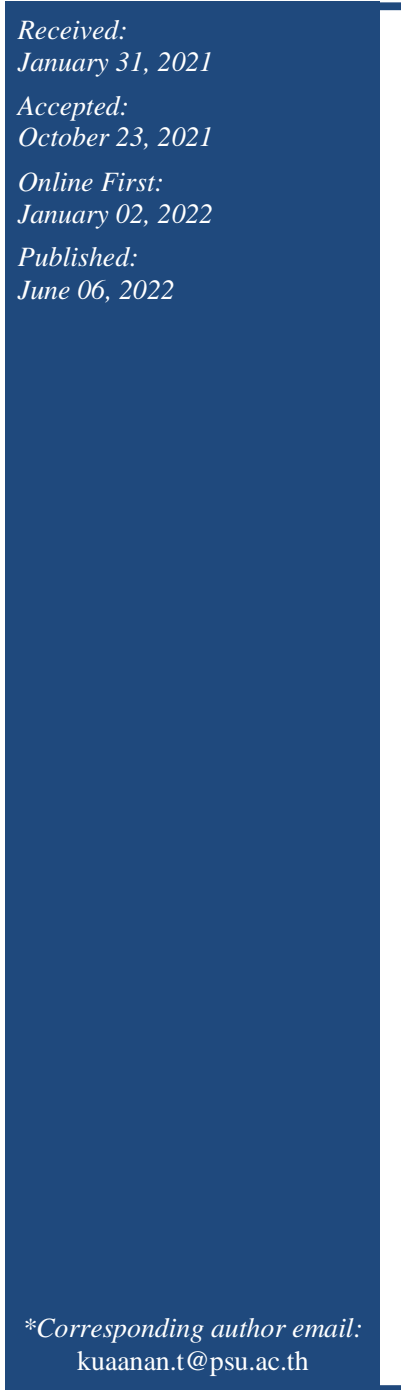

\begin{abstract}
Taro (Colocasia esculenta L. $c v$. Latiraj) is a vegetable for many people in tropical and sub-tropical countries in the world. Because of large quantities of vitamins and minerals, it has considerable value in the food market. As the Taro has raised market demand, it needs to increase production as much as possible. Agroforestry would be a possible production approach for Taro as it can be practised in a partially shaded conditions. The research aimed to evaluate the performance of Taro under woody perennials of Melia azedarach, Leucaena leucocephala, Albizia lebbeck and sole crop cultivation to get potential production and high financial return. This experiment was followed a single factor Randomized Complete Block Design (RCBD) with three replications. The treatments were (1) sole cropping of Latiraj, (2) Latiraj-Melia azedarach, (3) Latiraj-Albizia lebbeck and (4) Latiraj-Leucaena leucocephala. The results showed the maximum number of stolon per plant (29.50) found in LatirajAlbizia lebbeck and noted the minimum number of stolon (19.17) was in LatirajLeucaena leucocephala. Also, the highest stolon length $(60.85 \mathrm{~cm})$ and girth $(3.33$ $\mathrm{cm}$ ) were observed in Latiraj-Albizia lebbeck and Latiraj-Melia azedarach, respectively. Moreover, the highest stolon yield (10.08 ton/ha) was obtained from Latiraj-Albizia lebbeck compared to (9.85 ton/ha) Latiraj sole cropping. The maximum benefit-cost ratio (4.78) was recorded in the Latiraj-Albizia lebbeck, 24\% higher than (3.62) Latiraj sole cropping for economic performance. Finally, it was found that the Taro $c v$. Latiraj cultivation under Albizia lebbeck as an agroforestry practice would be a sustainable strategy to maximize the production, touching financial benefit and ensuring the proper utilization of vacant woodlots space.
\end{abstract}

Keywords: Aroid vegetable crop, Woody perennial trees, Agroforestry practices, Benefit-cost ratio, Monetary return

\section{How to cite this:}

Amin MHA, Sumi S, Jutidamrongphan W and Techato K, 2022. Economic potentiality of Colocasia esculenta L. under multipurpose tree-based agroforestry systems. Asian J. Agric. Biol. 2022(3): 202101059. DOI: https://doi.org/10.35495/ajab.2021.01.059.

This is an Open Access article distributed under the terms of the Creative Commons Attribution 3.0 License. (https://creativecommons.org/licenses/by/3.0), which permits unrestricted use, distribution, and reproduction in any medium, provided the original work is properly cited. 


\section{Introduction}

Panikachu (Colocasia esculenta L.) is one of the most common edible aroids belonging to the monocotyledonous Araceae family and extensively planted low-lying and swampy areas of the subtropical and tropical countries (Talwana et al., 2010; Mabhaudhi et al., 2014). The cultivar Latiraj (BARI panikachu 1) is well-known due to its stolon is a plenty source of vitamins and minerals (Temesgen and Retta, 2015). The stolon continually emerges from the base of the growing sucker corms. It is highly attractive, nutritive and delicious for cooking dish in everyday diet as it has good taste and non-acridity (Sen et al., 1998). Research revealed that the $100 \mathrm{~g}$ fresh stolon covers with iron $1.12 \mathrm{~g}$, calcium, $38 \mathrm{mg}$, vitamin A $500 \mathrm{IU}$, vitamin-C $38 \mathrm{mg}$ and food energy 35 Kilocalorie (Bhuiyan et al., 2008). In Bangladesh, this vegetable is very popular and it occupies an area of around 6,886 ha with a total stolon output of 38,502 tons and an average yield of 5.6 tons per hectare in 2016-2017 (BBS, 2017). The important issue is that this vegetable is appeared in the summer season, in the meanwhile the other vegetables are not as available in the market (Haque et al., 2013). Hassan (2017) reported that the urban morphology of major cities of Bangladesh is steadily increasing about $468 \%$ over the 41 -years by replacing agricultural arable land, resulting in a decrease in crop and vegetation covering $61.91 \%$ and $27.77 \%$ over the last decade. Around $65 \%$ of the population currently resides in rural areas and their livelihoods are mainly based on agricultural activities (World Bank, 2016). Besides, Hanif and Bari (2013) mentioned that the present scheme of land use with separate allocations for agriculture and forestry would not be adequate to meet the demands of the people living in rural communities. Agriculture without degrading agro-ecosystem resources while preserving or improving efficiency, resilience or, in other terms, sustainability, is a well-known reality (Bargali et al., 2004; Padalia et al., 2015). The multifood production system agroforestry that combines the trees and crops in the eco-friendly environment enhance the food safety, environmental stability and feasibility (Yasmin et al., 2010).

Agroforestry practices are being very popular, and time appropriate multi-production approach (Garrity, 2004) improves soil fertility and water holding capacity reduce soil erosion as well as conserve the biodiversity (Chakraborty et al., 2015). With the depletion of agricultural and forest resources, agroforestry can mitigate. It also relies sequentially or alongside seasonal trees on the planting of annual crops. It is a framework that can be ecological and environmentally responsive and assists people's socio-economic needs (Sharmin and Rabbi, 2016). It has compensated for the loss of agricultural and forestry land, increased public benefits, boosted ecosystem services, met the rural people's socioeconomic requirements, and mitigated the climate change issue (Amin et al., 2017a; Reppin et al., 2020). The goods harvested from agroforestry activities (food crops and tree resources) serve the multidimensional needs of rural peoples (Rahman et al., 2012). Growing wages and the involvement of women in production activities further alleviate poverty (Rahman et al., 2017).

The fast-growing small crown deciduous nitrogenfixing trees are chosen for agroforestry practices (Miah et al., 2002). Amin et al. (2017b) reported that Albizia lebbeck L. was found to have a significant role in achieving economic prosperity in an agroforestry-based production system. Instead, Leucaena leucocephala Lam. is commonly cultivated in subtropics, and tropics can provide an affordable source of plant biomass and help produce nutritious food. Melia azedarach L. is a deciduous tree widely spread in Asia, North America and Latin America renowned for its antioxidant use of leaf and fruit items that are environmentally friendly (Al-Rubae, 2009). Thus, there is a scope to use the vacant space of these woodlots to produce Taro cultivar Latiraj as agroforestry system by utilizing the natural resources for yield and economic benefits. According to the World Food Summit (1996), "Food security exists when all people, at all times, have physical, economic access to sufficient, safe, nutritious food that meets their dietary needs, food preferences for an active and healthy life". The purpose of the study has been taken to evaluate the yield potentiality and the economic performance of Taro cv. Latiraj cultivated under Melia azedarach, Albizia lebbeck and Leucaena leucocephala based agroforestry with sole cropping.

\section{Material and Methods}

\section{Study area}

The experiment was conducted at Agroforestry and Environment Research Farm of Hajee Mohammad Danesh Science and Technology University, Dinajpur. The research area was situated between 
latitude $\left(25^{\circ} 13^{\prime}\right)$ and longitude $\left(88^{\circ} 23^{\prime}\right)$ with an average height of $37.5 \mathrm{~m}$ from the sea level. The soil of the experimental unit was a medium high land fitting to Agro-Ecological Zone (AEZ) No. 01 the old Himalayan Piedmont Plain Area (UNDP-FAO, 1988). The soil texture and the chemical composition of the studied area have shown in table 1.

Table-1: The physical and chemical properties of soil in experimental field

\begin{tabular}{|l|c|}
\hline \multicolumn{1}{|c|}{ Soil characters } & $\begin{array}{c}\text { Physical and } \\
\text { chemical properties }\end{array}$ \\
\hline Sand $(\%)$ & 67 \\
\hline Silt $(\%)$ & 33 \\
\hline Clay $(\%)$ & 5 \\
\hline Textural class & Sandy loam \\
\hline CEC $($ meq/ $100 \mathrm{~g})$ & 8.0 \\
\hline $\mathrm{p}^{\mathrm{H}}$ & 5.1 \\
\hline Organic matter $(\%)$ & 1.25 \\
\hline Total nitrogen $(\%)$ & 0.12 \\
\hline Sodium $(\mathrm{meq} / 100 \mathrm{~g})$ & 0.05 \\
\hline Calcium $(\mathrm{meq} / 100 \mathrm{~g})$ & 1.33 \\
\hline Magnesium $(\mathrm{meq} / 100 \mathrm{~g})$ & 0.41 \\
\hline Potassium $(\mathrm{meq} / 100 \mathrm{~g})$ & 0.25 \\
\hline Phosphorus $(\mu \mathrm{g} / \mathrm{g})$ & 25.0 \\
\hline Sulphur $(\mu \mathrm{g} / \mathrm{g})$ & 3.1 \\
\hline Boron $(\mu \mathrm{g} / \mathrm{g})$ & 0.28 \\
\hline Iron $(\mu \mathrm{g} / \mathrm{g})$ & 5.30 \\
\hline Zinc $(\mu \mathrm{g} / \mathrm{g})$ & 0.90 \\
\hline
\end{tabular}

Source: Soil Resources Development Institute, Dinajpur

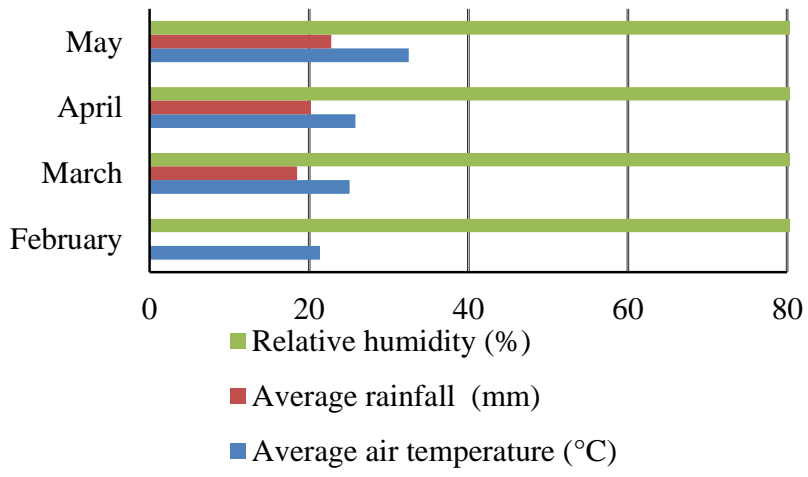

Figure-1: Weather data of the experimental site during the period from February to May 2019

Source: Meteorological Station, Wheat Research Center, Noshipur, Dinajpur

In the research area, the maximum average air temperature $\left(32.5^{\circ} \mathrm{C}\right)$ was in May, and the minimum average air temperature $\left(21.37^{\circ} \mathrm{C}\right)$ was recorded in February. Additionally, the highest average rainfall was measured $(22.8 \mathrm{~mm})$ in May, and the lowest average rainfall $(18.50 \mathrm{~mm})$ was observed in March, but in February, no rain occurred. The relative humidity was found more or less the same during all the months of the study area (Figure 1).

\section{Plant material}

The fifteen (15) years old woodlots of Melia azedarach, Leucaena leucocephala and Albizia lebbeck were used for the present research work. The plant to plant and row to row distance of the woodlots were 3 meters with east-west plant geometry. The average Melia azedarach tree height, clean bole height, base girth, bole girth and diameter at breast height were $18.8 \mathrm{~m}, 13.5 \mathrm{~m}, 105 \mathrm{~cm}, 84.6$ $\mathrm{cm}$ and $32 \mathrm{~cm}$, respectively. Besides, the average Leucaena leucocephala tree height, clean bole height, base girth, bole girth and diameter at breast height were $20.20 \mathrm{~m}, 15.5 \mathrm{~m}, 95 \mathrm{~cm}, 80.0 \mathrm{~cm}$ and $30 \mathrm{~cm}$, respectively. Likewise, the average Albizia lebbeck tree height, clean bole height, base girth, bole girth and diameter at breast height were $15.6 \mathrm{~m}, 10.5 \mathrm{~m}, 93$ $\mathrm{cm}, 54.6 \mathrm{~cm}$ and $25 \mathrm{~cm}$, respectively. The Latiraj (BARI panikachu 1) modern popular variety of Taro was the model crop.

\section{Experimental layout and treatments}

The experiment was laid out a single factor Randomized Complete Block Design (RCBD) with three (3) replications. The treatments were $T_{1}=$ sole cropping of Latiraj (control treatment), $\mathrm{T}_{2}=$ LatirajMelia azedarach agroforestry, $\mathrm{T}_{3}=$ Latiraj-Albizia lebbeck agroforestry and $\mathrm{T}_{4}=$ Latiraj-Leucaena leucocephala agroforestry. The size of the individual experimental plot was $2.5 \mathrm{~m} \times 2.5 \mathrm{~m}=6.25 \mathrm{~m}^{2}$. The total numbers of experimental plots were twelve (12).

\section{Crop establishment}

The land in the experimental plots was ploughed and the corners of the land not reached by the tillage machine were dug with a spade, and visibly larger clods were hammered to break them into small pieces. All weeds and stubbles were removed from the field. After ploughed the land, the organic manure cow dung (8 ton/ha) was applied (Rashid, 1993). Urea, triple superphosphate (TSP), muriate of potash (MP) and gypsum were applied as the source of nitrogen, phosphorus, potassium and sulphur (N-P-K- 
S 110-45-105-24 kg/ha), respectively as recommended by Noor et al., 2015 for the Taro production. The mentioned doses of urea, TSP, MP and gypsum was applied at the time of final land preparation in the experimental plots. The 30 days aged seedlings of Latiraj were planted in the experimental plots randomly maintaining the distance line to line $50 \mathrm{~cm}$ and plant to plant distance $50 \mathrm{~cm}$. Manual weeding was done as and when necessary to keep the plots completely free from all weeds. Provided Irrigations were throughout the growing period. The first one did at 15 days after planting. Subsequently, irrigations were given at 15 days intervals. After irrigation, the soil top surface was loosened to ensure good soil moisture.

\section{Data collection}

Data were recorded on the following parameters plant height, the number of leaves per plant, leaf length and leaf breadth at 30, 60 and 90 days after planting from the sample Latiraj plants during experimentation. Further, recorded yield and yield contributing characters (number of stolon per plant, stolon length, stolon girth, stolon yield per plot and stolon yield ton/ha). The price of stolon of Latiraj and the wood value of Melia azedarach, Leucaena leucocephala and Albizia lebbeck was estimated for economic analysis. The cost of cultivation, gross and net returns per hectare and benefit-cost ratio were calculated for the evaluation the of Taro economic benefit under Melia azedarach, Leucaena leucocephala and Albizia lebbeck along with sole cropping. Gross return is the monetary value of the total product and by-product and is measured by multiplying the total amount of production per hectare and market price. Net return = Gross return (US\$ per ha) - Total cost of production (US\$ per ha). Benefit-cost ratio is the ratio of gross return with total cost of production. It was calculated by using the following formula (Islam et al., 2004). Benefit-cost ratio $=$ Gross return (US\$ per ha) $/$ Total cost of production (US\$ per ha).

\section{Statistical analysis}

The statistical data analysis includes Analysis of Variance (ANOVA), which was accomplished using the computer package MSTAT-C software. The mean differences were arranged by (DMRT) the Duncan's Multiple Range Test (Gomez and Gomez, 1984).

\section{Results and Discussion}

\section{Effect of multipurpose tree-based agroforestry system on the growth of Taro}

Taro $c v$. Latiraj plant height was found statistically insignificant at 30 days after planting (DAP) (Table 2). But, at 60 DAP the plant height was found significantly different among the treatments. The highest plant height $(60.54 \mathrm{~cm})$ was recorded in $\left(\mathrm{T}_{2}\right)$ treatment Latiraj-Melia azedarach agroforestry system followed by $(56.13 \mathrm{~cm})$ Latiraj-Albizia lebbeck agroforestry system $\left(\mathrm{T}_{3}\right)$. The lowest plant height $(50.33 \mathrm{~cm})$ was noted in $\left(\mathrm{T}_{1}\right)$ Latiraj sole cropping that was similar to $(50.93 \mathrm{~cm})$ in $\left(\mathrm{T}_{4}\right)$ treatment. The trend of growing Taro plant height was changed dramatically in 90 DAP. The highest plant height $(87.88 \mathrm{~cm})$ was recorded in $\left(\mathrm{T}_{2}\right)$ treatment that was identical to $\left(\mathrm{T}_{3}\right)(87.20 \mathrm{~cm})$ and $\left(\mathrm{T}_{4}\right)(85.57 \mathrm{~cm})$ treatments. Conversely, the lowest plant height $(81.84 \mathrm{~cm})$ was noted in $\left(\mathrm{T}_{1}\right)$ sole cropping of Latiraj (Table 2). Hillman (1984) reported that plants cultivated in low light levels are more apical dominant than those grown in high light conditions resulting in taller plants under the shade. Growth features are typically used to imply species tolerance to light availability (Teixeira et al., 2015). From the findings, plant height was more prominent in Latiraj-Melia azedarach agroforestry system. Because of Latiraj plant received a good portion of the light that assists the photosynthesis activity. Cavatte et al. ( 2009) reported that sunlight affected the germination and growth of the plants.

Table-2: Effect of multipurpose tree-based agroforestry systems on plant height of Taro

\begin{tabular}{|c|c|c|c|}
\hline \multirow{2}{*}{ Treatments } & \multicolumn{3}{|c|}{ Plant height (cm) } \\
\cline { 2 - 4 } & 30 DAP & 60 DAP & 90 DAP \\
\hline $\mathrm{T}_{1}$ & $25.50 \mathrm{a}$ & $50.33 \mathrm{c}$ & $81.84 \mathrm{~b}$ \\
\hline $\mathrm{T}_{2}$ & $20.02 \mathrm{a}$ & $60.54 \mathrm{a}$ & $87.88 \mathrm{a}$ \\
\hline $\mathrm{T}_{3}$ & $24.36 \mathrm{a}$ & $56.13 \mathrm{~b}$ & $87.20 \mathrm{a}$ \\
\hline $\mathrm{T}_{4}$ & $25.15 \mathrm{a}$ & $50.93 \mathrm{c}$ & $85.57 \mathrm{ab}$ \\
\hline $\mathrm{CV} \%$ & 27.04 & 1.81 & 1.97 \\
\hline
\end{tabular}

Columns having the similar letters means that treatments do not differ significantly, and dissimilar letters mean that treatments differ significantly by Duncan's Multiple Range Test (DMRT) at $\mathrm{P} \leq 5 \%$.

Number of leaves per plant of Latiraj was observed statistically significant at 60 and 90 DAP (Table 3). At 60 DAP, the maximum number of leaves per plant (5.80) was recorded in $\left(\mathrm{T}_{3}\right)$ Latiraj-Albizia lebbeck 
agroforestry system that was statistically identical to 5.67 and 5.60 was taken in both $\mathrm{T}_{1}$ and $\mathrm{T}_{2}$ treatments, respectively. Besides, the minimum number of leaves per plant (4.50) was observed in $\left(\mathrm{T}_{4}\right)$ LatirajLeucaena leucocephala agroforestry. Finally, the maximum number of leaves per plant (6.17) was observed in $\left(\mathrm{T}_{1}\right)$ sole cropping of Latiraj, and the minimum number of leaves per plant (5.27) was observed in $\left(\mathrm{T}_{4}\right)$ Latiraj-Leucaena leucocephala agroforestry at 90 DAP (Table 3). The results also supported by Gondim et al. (2007) mention that vegetative growth of Latiraj is to begin with moderately slow, afterwards, it progresses smoothly between two and three months with a subsequent leaf numbers, leaf area, petiole length and plant height. Pereira et al. (2006) was also found a significant leaves growth and development of Taro when it cultivated in a glasshouse. According to Onwueme and Johnston (2000), Taro grown in shade showed increased stomatal density in both the top and lower epidermis. This taro reaction was proposed as a potential indication of the species more impressive shade adaptation, since shadowing happens often under normal growth circumstances in different cropping systems (for example, intercropping, alley cropping).

Table-3. Effect of multipurpose tree-based agroforestry systems on leaves per plant of Taro

\begin{tabular}{|c|c|c|c|}
\hline \multirow{2}{*}{ Treatments } & \multicolumn{3}{|c|}{ Number of leaves per plant } \\
\cline { 2 - 4 } & 30 DAP & 60 DAP & 90 DAP \\
\hline $\mathrm{T}_{1}$ & $1.67 \mathrm{a}$ & $5.67 \mathrm{a}$ & $6.17 \mathrm{a}$ \\
\hline $\mathrm{T}_{2}$ & $1.53 \mathrm{a}$ & $5.60 \mathrm{a}$ & $5.80 \mathrm{~b}$ \\
\hline $\mathrm{T}_{3}$ & $1.53 \mathrm{a}$ & $5.80 \mathrm{a}$ & $5.87 \mathrm{~b}$ \\
\hline $\mathrm{T}_{4}$ & $1.53 \mathrm{a}$ & $4.50 \mathrm{~b}$ & $5.27 \mathrm{c}$ \\
\hline $\mathrm{CV} \%$ & 8.44 & 4.32 & 1.66 \\
\hline
\end{tabular}

Columns having the similar letters means that treatments do not differ significantly, and dissimilar letters mean that treatments differ significantly by Duncan's Multiple Range Test (DMRT) at $\mathrm{P} \leq 5 \%$.

It was found significantly different on leaf length at 30, 60 and 90 DAP (Table 4). Firstly, the highest leaf length $(30.50 \mathrm{~cm})$ was recorder in $\left(\mathrm{T}_{4}\right)$ treatment similar to $(28.97 \mathrm{~cm})$ in $\left(\mathrm{T}_{2}\right)$ treatment. The lowest leaf length $(21.17 \mathrm{~cm})$ was recorded in $\left(T_{1}\right)$ sole cropping of Latiraj at 30 DAP. In the middle stage, at 60 DAP, the highest leaf length $(45.43 \mathrm{~cm})$ was observed in $\left(\mathrm{T}_{4}\right)$ treatment followed by $(41.50 \mathrm{~cm})$ in $\mathrm{T}_{2}$ Treatment. In contrast, the lowest leaf length $(30.38 \mathrm{~cm})$ was recorded in $\mathrm{T}_{1}$ sole cropping of
Latiraj. Lastly, at 90 DAP, the highest leaf length $(65.80 \mathrm{~cm})$ was found in $\left(\mathrm{T}_{4}\right)$ Latiraj-Leucaena leucocephala agroforestry followed by $(61.83 \mathrm{~cm})$ in $\left(\mathrm{T}_{2}\right)$ Latiraj-Melia azedarach agroforestry system. The lowest leaf length $(50.45 \mathrm{~cm})$ was recorded in $\left(\mathrm{T}_{1}\right)$ sole cropping of Latiraj (Table 4). In agroforestry practice, the tree canopy shade can reduce the direct sun light to the plants, resulting the plants can receive the effective sun light that proceed the photosysthesis activities. In horticultural crops, it has been commonly assumed that long-term exposure to far-red (FR) initiates events resulting in higher carbohydrate accumulation in the leaves and roots than that of red (R) light received a plant, affecting fruit setting (Kasperbahuer, 2000; Glenn and Puterka, 2007). For this reason the leaf growth almost more in all the treatments compare to control sole cropping. Gondim et al. (2007) said that shade influenced the microclimate, reducing the air temperature brings better leaf growth.

Table-4: Effect of multipurpose tree-based agroforestry systems on leaf length of Taro

\begin{tabular}{|c|c|c|c|}
\hline \multirow{2}{*}{ Treatments } & \multicolumn{3}{|c|}{ Leaf length $(\mathbf{c m})$} \\
\cline { 2 - 4 } & 30 DAP & 60 DAP & 90 DAP \\
\hline $\mathrm{T}_{1}$ & $21.17 \mathrm{c}$ & $30.83 \mathrm{~d}$ & $50.45 \mathrm{~d}$ \\
\hline $\mathrm{T}_{2}$ & $28.97 \mathrm{a}$ & $41.50 \mathrm{~b}$ & $61.83 \mathrm{~b}$ \\
\hline $\mathrm{T}_{3}$ & $24.60 \mathrm{~b}$ & $35.60 \mathrm{c}$ & $55.93 \mathrm{c}$ \\
\hline $\mathrm{T}_{4}$ & $30.50 \mathrm{a}$ & $45.43 \mathrm{a}$ & $65.80 \mathrm{a}$ \\
\hline $\mathrm{CV} \%$ & 2.80 & 0.81 & 0.95 \\
\hline
\end{tabular}

Columns having the similar letters means that treatments do not differ significantly, and dissimilar letters mean that treatments differ significantly by Duncan's Multiple Range Test (DMRT) at $\mathrm{P} \leq 5 \%$.

Significantly varied leaf breadth was observed through the growing period of Taro (Table 5). At the early stage, 30 DAP the highest leaf breadth (11.60 $\mathrm{cm})$ was recorded in $\left(\mathrm{T}_{2}\right)$ treatment which was identical to $(11.33 \mathrm{~cm})$ found in $\mathrm{T}_{4}$ treatment. The lowest leaf breadth $(8.23 \mathrm{~cm})$ was recorded in $\mathrm{T}_{1}$ Latiraj sole cropping which was similar to $8.83 \mathrm{~cm}$ in $\mathrm{T}_{3}$ treatment. At $60 \mathrm{DAP}$, the highest leaf breadth $(26.83 \mathrm{~cm})$ was observed in $\left(\mathrm{T}_{4}\right)$ treatment followed by $25.83 \mathrm{~cm}$ in $\left(\mathrm{T}_{2}\right)$ treatment. The lowest leaf breadth $(18.67 \mathrm{~cm})$ was recorded in sole cropping of Latiraj $\left(\mathrm{T}_{1}\right)$. Finally, at $90 \mathrm{DAP}$, the highest leaf breadth $(35.83 \mathrm{~cm})$ was found in $\left(\mathrm{T}_{4}\right)$ LatirajLeucaena leucocephala agroforestry followed by $(32.83 \mathrm{~cm})$ in $\left(\mathrm{T}_{2}\right)$ Latiraj-Melia azedarach agroforestry system but the lowest leaf breadth 
$(25.50 \mathrm{~cm})$ was recorded in $\left(\mathrm{T}_{1}\right)$ sole cropping of Latiraj (Table 5). Oliveira et al. (2011) noted that reducing light assists the leaf and root growth and development of Chinese Taro plants.

Table-5: Effect of multipurpose tree-based agroforestry systems on leaf breadth of Taro

\begin{tabular}{|c|c|c|c|}
\hline \multirow{2}{*}{ Treatments } & \multicolumn{3}{|c|}{ Leaf breadth (cm) } \\
\cline { 2 - 4 } & 30 DAP & 60 DAP & 90 DAP \\
\hline $\mathrm{T}_{1}$ & $8.23 \mathrm{~b}$ & $18.67 \mathrm{~d}$ & $25.50 \mathrm{~d}$ \\
\hline $\mathrm{T}_{2}$ & $11.60 \mathrm{a}$ & $25.83 \mathrm{~b}$ & $32.83 \mathrm{~b}$ \\
\hline $\mathrm{T}_{3}$ & $8.83 \mathrm{~b}$ & $24.63 \mathrm{c}$ & $30.50 \mathrm{c}$ \\
\hline $\mathrm{T}_{4}$ & $11.33 \mathrm{a}$ & $26.83 \mathrm{a}$ & $35.83 \mathrm{a}$ \\
\hline $\mathrm{CV} \%$ & 6.36 & 0.86 & 1.93 \\
\hline
\end{tabular}

Columns having the similar letters means that treatments do not differ significantly, and dissimilar letters mean that treatments differ significantly by Duncan's Multiple Range Test (DMRT) at $\mathrm{P} \leq 5 \%$.

\section{Effect of multipurpose tree-based agroforestry system on the yield of Taro}

The stolon number per plant of Taro $c v$. Latiraj was found highly significant due to the effect of multipurpose tree-based agroforestry system. Table 6 showed that the highest stolon number per plant (29.50) was noted in Latiraj-Albizia lebbeck agroforestry system $\left(\mathrm{T}_{3}\right)$ followed by 25.67 in $\mathrm{T}_{1}$ treatment. The lowest number of stolon per plant (19.17) was recorded in Latiraj-Leucaena leucocephala agroforestry $\left(\mathrm{T}_{4}\right)$. The stolon number per plant was more as the Albizia lebbeck woodlots gave effective light penetration to the growing period of Taro. Under low light conditions, the distribution patterns of photoassimilates can shift but the moderate light condition may be lead the better photosysthesis of Taro. Usually, photoassimilates directed to the reserve organs are decreased and meristematic regions are expanded (Monim et al., 2010). In stolon length, we found an effective variation among the treatments. The results indicated that the tallest stolon length $(60.85 \mathrm{~cm})$ was recorded in $\left(\left(\mathrm{T}_{3}\right)\right.$ Latiraj-Albizia lebbeck agroforestry system followed by $(60.75 \mathrm{~cm})$ in $\left(\mathrm{T}_{1}\right)$ sole cropping of Latiraj and $(56.64 \mathrm{~cm})$ in Latiraj-Melia azedarach agroforestry system $\left(\mathrm{T}_{2}\right)$. But, the shortest stolon length $(50.08 \mathrm{~cm})$ was observed in $\left(\mathrm{T}_{4}\right)$ LatirajLeucaena leucocephala agroforestry. The stolon length is highly depending on the soil organic nitrogen condition and also the movement and exchange of the nutrients of the soil to the plants. Moklyachuk et al. (2019) mentioned that organic fertilizers and biological nitrogen fixation need to be utilized to preserve the productivity of the land. Albizia lebbeck agroforestry system plays a substantial role to restore the soil fertility. Behera et al. (2015) reported that multipurpose woodlot agroforestry a choice for restoring soil quality and upgrading salt-affected soils to further increase yields. The stolon girth of Latiraj was coined statistically significant by the effects of multipurpose tree-based agroforestry system. Significantly the maximum stolon girth $(3.33 \mathrm{~cm})$ was recorded in $\left(\mathrm{T}_{2}\right)$ Latiraj-Melia azedarach agroforestry system which was followed by $(3.29 \mathrm{~cm})$ from Latiraj-Albizia lebbeck agroforestry system. On the other hand, the minimum stolon girth $(1.30 \mathrm{~cm})$ was observed in $\left(\mathrm{T}_{4}\right)$ Latiraj-Leucaena leucocephala agroforestry, respectively. The stolon yield $\mathrm{kg} / \mathrm{plot}$ of Latiraj was found variedly significant among the treatments. We found the highest stolon yield per plot $(6.30 \mathrm{~kg})$ in Latiraj-Albizia lebbeck agroforestry system $\left(\mathrm{T}_{3}\right)$ which was statistically identical to $(6.16 \mathrm{~kg})$ observed in sole cropping of Latiraj $\left(\mathrm{T}_{1}\right)$ followed by $(3.39 \mathrm{~kg})$ in $\left(\mathrm{T}_{2}\right)$ Latiraj-Melia azedarach agroforestry system. Besides, the lowest stolon yield per plot $(2.18 \mathrm{~kg})$ was measured in $\left(\mathrm{T}_{4}\right)$ Latiraj-Leucaena leucocephala agroforestry (Table 6). Moreover, the highest stolon yield (10.08 ton/ha) was weighed in Latiraj-Albizia lebbeck agroforestry system $\left(\mathrm{T}_{3}\right)$ and the second highest stolon yield (9.85 ton/ha) was found in $\left(\mathrm{T}_{1}\right)$ sole cropping of Latiraj. Conversely, the lowest stolon yield (3.49 ton/ha) was measured in LatirajLeucaena leucocephala agroforestry $\left(\mathrm{T}_{4}\right)$ followed by (7.42 ton/ha) in Latiraj-Melia azedarach agroforestry system $\left(\mathrm{T}_{2}\right)$, respectively (Figure 2). According to van der Werf et al. (2007) tree-based agroforestry subsidize to modern diversified land usage, such as increased biodiversity and sustainability, decreased nitrogen leaching, protection against flooding and erosion, and landscape attractiveness. In the present research, Albizia lebbeck agroforestry practice creates an important collaboration with Taro production. Oyebamiji et al. (2017) express that Albizia lebbeck tree had high potentiality to accelerate the growth and yield of crops. As Lenhard et al. (2013) reported that plants below $70 \%$ of shading had higher total rates of chlorophyll, leaf area and weight ratios. Albizia lebbeck is a deciduous tree it creates a moderate shade for the crops. An analysis on artificial shade on Taro (Colocasia esculenta) was performed by Gondim et al. (2018) and the results were the shading strength of 18 percent, over the entire cycle or in 
some of the cycles tested, provides a high expansion of the development and growth of the crops. Furthermore, Gondim et al. (2018) also recommended to cultivate Taro (Colocasia esculenta) in an intercropping system. The present research results state the performance of Taro $c v$. Latiraj is more potential and productive under Albizia lebbeck agroforestry practice.

Table-6. Effect of multipurpose tree-based agroforestry systems on stolon number, length, girth and yield (kg/plot) of Taro

\begin{tabular}{|c|c|c|c|c|}
\hline Treatments & $\begin{array}{c}\text { Stolon } \\
\text { number } \\
\text { per plant }\end{array}$ & $\begin{array}{c}\text { Stolon } \\
\text { length } \\
(\mathbf{c m})\end{array}$ & $\begin{array}{c}\text { Stolon } \\
\text { girth }(\mathbf{c m})\end{array}$ & $\begin{array}{c}\text { Yield } \\
(\mathbf{k g} / \mathbf{p l o t})\end{array}$ \\
\hline $\mathrm{T}_{1}$ & $25.67 \mathrm{~b}$ & $60.75 \mathrm{a}$ & $3.11 \mathrm{c}$ & $6.16 \mathrm{a}$ \\
\hline $\mathrm{T}_{2}$ & $22.50 \mathrm{c}$ & $56.64 \mathrm{~b}$ & $3.33 \mathrm{a}$ & $3.39 \mathrm{~b}$ \\
\hline $\mathrm{T}_{3}$ & $29.50 \mathrm{a}$ & $60.85 \mathrm{a}$ & $3.29 \mathrm{~b}$ & $6.30 \mathrm{a}$ \\
\hline $\mathrm{T}_{4}$ & $19.17 \mathrm{~d}$ & $50.08 \mathrm{c}$ & $1.30 \mathrm{~d}$ & $2.18 \mathrm{c}$ \\
\hline $\mathrm{CV} \%$ & 2.82 & 1.72 & 10.28 & 7.67 \\
\hline
\end{tabular}

Columns having the similar letters means that treatments do not differ significantly, and dissimilar letters mean that treatments differ significantly by Duncan's Multiple Range Test (DMRT) at $\mathrm{P} \leq 5 \%$.

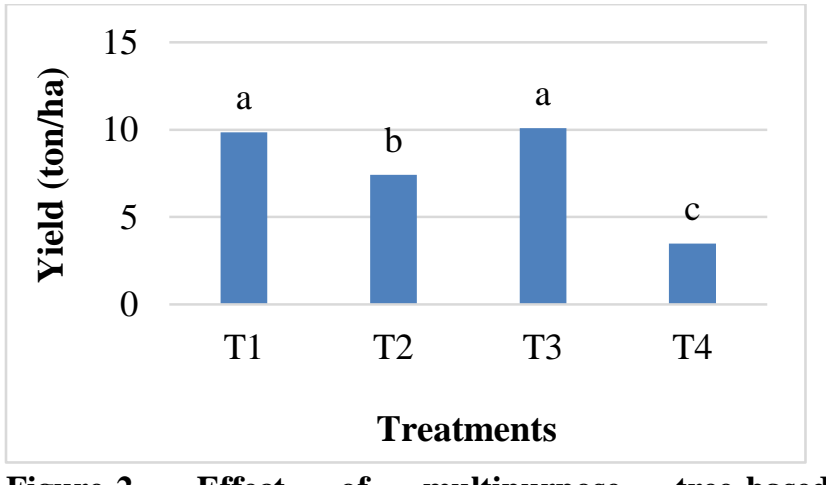

Figure-2. Effect of multipurpose tree-based agroforestry system on stolon yield (ton/ha) of Taro

In the figure, bars having similar letters mean treatments do not differ significantly and dissimilar letters mean treatments significantly differ by Duncan's Multiple Range Test (DMRT)) at $\mathrm{P} \leq 5 \%$.
Economic performance of Taro under multipurpose tree based agroforestry system

From table 7, we found a significant variation in cost of production, gross return, net return, and benefitcost ratio in different treatments. The highest cost of production (US\$ 1924.95 per ha) was recorded in $\left(\mathrm{T}_{4}\right)$ Latiraj-Leucaena leucocephala followed by (US\$ 1592.06 per ha) in $\left(\mathrm{T}_{2}\right)$ treatment whereas, the lowest cost of production (US\$ 960.35 per ha) was recorded in sole cropping of Latiraj $\left(\mathrm{T}_{1}\right)$. The highest gross return (US\$ 6145.89 per ha) was obtained from Latiraj-Albizia lebbeck $\left(\mathrm{T}_{3}\right)$ and the lowest gross return (US\$ 3349.41 per ha) was found in $\left(\mathrm{T}_{4}\right)$ treatment. The maximum net return (US\$ 4860.14 per ha) was recorded in $\left(\mathrm{T}_{3}\right)$ treatment Latiraj-Albizia lebbeck agroforestry and the minimum net return (US\$ 1424.46 per ha) was found in $\left(\mathrm{T}_{4}\right)$ treatment Latiraj-Leucaena leucocephala agroforestry. The benefit-cost ratio (4.78) was recorded maximum from Latiraj-Albizia lebbeck agroforestry $\left(\mathrm{T}_{3}\right)$ followed by (3.62) found in Latiraj sole cropping production $\left(\mathrm{T}_{1}\right)$ and the minimum benefit-cost ratio (1.74) was observed in Latiraj-Leucaena leucocephala agroforestry $\left(\mathrm{T}_{4}\right)$, respectively. In the research findings, we found the benefit-cost ratio of Taro $c v$. Latiraj under Albizia lebbeck agroforestry higher than Melia azedarach and Leucaena leucocephala agroforestry and also sole cropping. Thus, we can say commercially Taro $c v$. Latiraj production under Albizia lebbeck agroforestry will be more profitable and sustainable crop production approach for higher return of money. Amin et al. (2017a) noted that onion production under Albizia lebbeck tree-based agroforestry practises has the highest benefit-cost ratio when compared to current farming strategies; agroforestry practises would provide numerous sales opportunities without increasing risk and have a greater potential for addressing environmental issues than current farming methods for acceptance (AFTA, 2006).

Table-7. The gross return, the net return, total cost of production and benefit-cost ratio (BCR) of Taro cultivated under Albizia lebbeck, Melia azedarach, Leucaena leucocephala and sole cropping

\begin{tabular}{|c|c|c|c|c|c|c|c|c|}
\hline \multirow[b]{2}{*}{ Treatment } & \multicolumn{4}{|c|}{ Return (US\$/ha) } & \multirow{2}{*}{$\begin{array}{l}\text { Gross } \\
\text { return } \\
(\$ / h a)\end{array}$} & \multirow{2}{*}{$\begin{array}{c}\text { Total cost of } \\
\text { production } \\
(\$ / \mathrm{ha})\end{array}$} & \multirow{2}{*}{$\begin{array}{c}\text { Net } \\
\text { return } \\
(\$ / h a)\end{array}$} & \multirow[b]{2}{*}{ BCR } \\
\hline & Taro & $\begin{array}{c}\text { Melia } \\
\text { azedarach }\end{array}$ & $\begin{array}{l}\text { Albizia } \\
\text { lebbeck }\end{array}$ & $\begin{array}{c}\text { Leucaena } \\
\text { leucocephala }\end{array}$ & & & & \\
\hline $\mathrm{T}_{1}$ & 3476.47 & & $\ldots \ldots \ldots$ & f...... & 3476.47 & 960.35 & 2516.12 & 3.62 \\
\hline $\mathrm{T}_{2}$ & 1912.94 & 1764.71 & $\ldots \ldots \ldots$ & ......... & 3677.65 & 1592.06 & 2085.59 & 2.31 \\
\hline $\mathrm{T}_{3}$ & 3557.65 & $\ldots \ldots \ldots$ & 2588.24 & $\ldots \ldots \ldots$ & 6145.89 & 1285.75 & 4860.14 & 4.78 \\
\hline $\mathrm{T}_{4}$ & 1231.76 & $\ldots \ldots$ & $\ldots \ldots \ldots$ & 2117.65 & 3349.41 & 1924.95 & 1424.46 & 1.74 \\
\hline
\end{tabular}

Note: Taro $c v$. Latiraj stolon market price (US\$ 0.35/kg), Melia azedarach (US\$ 3.53/Tree/Year), Albizia lebbeck (US\$ 5.88/Tree/Year) and Leucaena leucocephala (US\$ 4.12/Tree/Year). 


\section{Conclusion}

The research finding has explored that Taro cv. Latiraj can significantly grow under Albizia lebbeck multipurpose woodlot-based agroforestry with effectively and economically. These combined production techniques potentially are occupied a dynamic part for bringing more than four times higher economic return on investment. Finally, the research results may be an effective outline for the government forest department as they can use their forest space to produce Taro. Furthermore, these research findings would broaden the opportunity to extend the Taro production under the other woody perennials in the agroforestry system.

\section{Acknowledgement}

The authors would like to express sincere gratitude to the Department of Agroforestry and Environment of Hajee Mohammad Danesh Science and Technology University, Dinajpur-5200, Bangladesh, for supporting the research work. The authors would also like to thank the Faculty of Environmental Management, Prince of Songkla University, Hat Yai, 90110, Songkhla, Thailand.

Disclaimer: None.

Conflict of Interest: None.

Source of Funding: This study was financially supported by the graduate studies grant under the research fund, Faculty of Environmental Management, Prince of Songkla University, Songkhla, Thailand.

\section{References}

AFTA, 2006. "An Introduction to Temperate Agroforestry." Available at http://www.aftaweb.org/; (accessed on January 2021).

Al-Rubae AY, 2009. The potential uses of Melia azedarach L. as pesticidal and medicinal plant, review. Am.-Eurasian J. Sustain. Agric. 3: 185194.

Amin MHA, Bormon SC and Kajal M, 2017a. Organic production of tomato under multipurpose tree-based agroforestry as influenced by mulching. Bangladesh Res. Pub. J. 12: 222-231.
Amin MHA, Roy JP, Rahman MS and Kajal M, 2017b. Economic performance of onion under Albizia lebbeck, Melia azedarach and Leucaena leucocephala based agroforestry systems. J. Innov. Dev. Strategy. 11:1-8.

Bargali SS, Singh SP and Pandya KS, 2004. Effects of Acacia nilotica on gram crop in a traditional agroforestry system of Chhattisgarh plains. Int. J. Ecol. Environ. Sci. 30: 363-368.

BBS, 2017. Yearbook of agricultural statistics-2017. Bangladesh Bureau of Statistics. Ministry of Planning. Government of the People's Republic of Bangladesh, Dhaka, Bangladesh.

Behera L, Nayak MR, Patel D, Mehta A, Sinha SK and Gunaga R, 2015. Agroforestry practices for physiological amelioration of salt affected soils. J. Plant Stress Physiol. 13-18.

Bhuiyan MKR, Rahman MM, Alam MS, Islam ATMT, Hossain M and Begum SN, 2008. Production technology of newly released aroids variety (In Bangla). Tuber Crops Research Centre, Bangladesh Agricul. Res. Inst., Gazipur: TCRC Publication.

Cavatte PC, Zonta JB, Lopes JC, de Souza LT, Zonta JH and Cavatte RPQ, 2009. Germination and vigor of carrot seeds in limestone mining soil under different light intensities and fertilizations. Idesia. 27: 25-32.

Chakraborty M, Haider MZ, Rahaman MM, 2015. Socio-economic impact of cropland agroforestry: evidence from Jessore District of Bangladesh. Int. J. Res. Agric. For. 22: 11-20.

Garrity DP, 2004. Agroforestry and the achievement to the millennium development goals. Agrofor. Syst. 61: 5-17.

Glenn DM and Puterka GJ, 2007. The use of plastic films and sprayable reflective particle films to increase light penetration in apple canopies and improved apple color and weight. Hort. Sci. 42: 91-96.

Gomez KA and Gomez AA, 1984. Statistical Procedures for Agricultural Research, 2nd eds. John Wiley and Sons, Inc. New York, USA.

Gondim ARDO, Puiatti M, Cecon PR and Finger FL, 2007. Growth, assimilated partition and yield of Taro corms 'Japonês' under different intensity and shading periods. Hortic. Bras. 25: 418-428.

Gondim ARDO, Puiatti M, Finger FL and Cecon PR, 2018. Artificial shading promotes growth of Taro plants. Pesqui. Agropecu. Trop. 48: 83-89. 
Hanif MA and Bari MS, 2013. Potentiality of potato based agrisilvicultural land use system in the northern part of Bangladesh. Sci. Secure J. Biotech. 2: 61-65.

Haque MA, Miah MM, Hossain S and Luna AN, 2013. Panikachu (Calocasis esculenta L. Schott) cultivation in some selected areas of Bangladesh: an agro-economic profile. Bangladesh J. Agric. Res. 38: 505-513.

Hassan MM, 2017. Monitoring land use/land cover change, urban growth dynamics and landscape pattern analysis in five fastest urbanized cities in Bangladesh. Remote Sens. Appl. Soc. Environ. 7: 69-83.

Hillman JR, 1984. Apical dominance, In: Wilking, M.b. (ed). Advanced plant physiology. Pitman, London, UK.

Islam MA, Sharfuddin AFM and Islam N, 2004. A study on production technology and disease management of ginger and turmeric in selected areas of Bangladesh. Bangladesh J. Crop Sci. 1315: 103-110.

Kasperbahuer MJ, 2000. Phytochrome in crop production. (in) Wilkinson RE (ed.) PlantEnvironment interactions. Marcel Dekker, New York, USA.

Lenhard NR, Paiva Neto VBD, Scalon SDPQ and Alvarenga AAD, 2013. Growth of Caesalpinia ferrea seedlings under different shading levels. Pesqui. Agropecu. Trop. 43: 178-186.

Mabhaudhi T, Modi AT and Beletse YG, 2014. Parameterisation and evaluation of the FAOAquaCrop model for a South African Taro (Colocasia esculenta L. Schott) landrace. Agric. Forest. Meteorol. 192: 132-139.

Miah MG, Ahmed FU, Ahmed MM, Alam MN, Choudhury NH and Hamid MA, 2002. Agroforestry in Bangladesh: potentials and opportunities, paper presented in South Asia Regional Agroforestry Consultation workshop held on 23-25 November, 2002 at New Delhi, India.

Moklyachuk L, Furdychko O, Pinchuk V, Mokliachuk O and Draga M, 2019. Nitrogen balance of crop production in Ukraine. J. Environ. Manage. 246: 860-867.

Monim MA, Islam ABMS, Rahman AKMA, Monim ASMA and Quddus MA, 2010. Effect of intercropping different vegetables with groundnut. J. Agroforest. Environ. 4: 27-30.
Noor S, Talukder MR, Bhuiyan MKR, Islam MM, Haque MA and Akhter S, 2015. Development of fertilizer recommendation for aquatic Taro (Colocasia esculenta) in grey terrace soil. Pertanika J. Trop. Agric. Sci. 38: 83-92.

Oliveira FLD, Araújo AP and Guerra JGM, 2011. Growth and nutrient accumulation of Taro plants under artificial shading levels. Hortic. Bras. 29: 292-298.

Onwueme IC and Johnston M, 2000. Influence of shade on stomatal density, leaf size and other leaf characteristics in the major tropical root crops, Tannia, Sweet potato, Yam, Cassava and Taro. Expl. Agric. 36: 509-516.

Oyebamiji NA, Babalola OA and Aduradola AM, 2017. Decomposition and nitrogen release patterns of Parkia biglobosa and Albizia lebbeck leaves with nitrogen fertilizer for maize production in Sudan savanna alfisol of Nigeria. J. Trop. Forest. Environ. 7: 54-64.

Padalia K, Bargali K and Bargali SS, 2015. How does traditional home-gardens support ethnomedicinal values in Kumaun Himalayan bhabhar belt, India. Afr. J. Tradit. Complement. Altern. Med. 12: 100-112.

Pereira FH, Puiatti M, Fontes PC and Aquino LA, 2006. Biomass accumulation, yield and "Metsubure" incidence in Taro corms submitted to potassium rates, with and without calcium application. Hortic. Bras. 24: 17-21.

Rahman MA, Tani M, Asahiro K and Ullah SA, 2017. Species composition, diversity and productivity of homesteads in southeastern Bangladesh. Small Scale For. 16: 295-309.

Rahman SA, Imam MH, Snelder DJ and Sunderland T, 2012. Agroforestry for livelihood security in Agrarian landscapes of the Padma floodplain in Bangladesh. Small Scale Forest. 11: 529-538.

Rashid MM, 1993. Sabgi Biggan (in Bangla). Rashid Publishing House, Dhaka, Bangladesh.

Reppin S, Kuyah S, de Neergaard A, Oelofse M and Rosenstock TS, 2020. Contribution of agroforestry to climate change mitigation and livelihoods in Western Kenya. Agroforest. Syst. 94: 203-220.

Sen H, Das S and Dwivedi AK, 1998. Stolon production of different organic and inorganic nitrogenous fertilizers. J. Root Crops. 24: 81-84.

Sharmin A and Rabbi SA, 2016. Assessment of farmers' perception of agroforestry practices in 
Md. Hafiz All Amin et al

Jhenaidah District of Bangladesh. J. Agric. Ecol. Res. Int. 6: 1-10.

Talwana HL, Tumuhimbise R and Osiru DSO, 2010. Comparative performance of wetland Taro grown in upland production system as influenced by different plant densities and seedbed preparation in Uganda. J. Root Crops. 36: 65-71.

Teixeira GCDS, Stone LF and Heinemann AB, 2015. Solar radiation use efficiency and morphophysiological indices in common bean cultivars. Pesqui. Agropecu. Trop. 45: 9-17.

Temesgen $M$ and Retta N, 2015. Nutritional potential, health and food security benefits of Taro Colocasia esculenta (L.): A review. Food Sci. Quality Manage. 36: 23-30.

UNDP-FAO (United Nations Development Programme-Food and Agriculture Organization of the United Nations), 1988. Land resources appraisal of Bangladesh for agricultural development. Technical Report 2 (BGD/81/035). Agroecological Regions of Bangladesh. Rome, Italy. 570.

van der Werf W, Keesman K, Burgess P, Graves A, Pilbeam D, Incoll LD and Dupraz C, 2007. Yield-SAFE: A parameter-sparse, process-based dynamic model for predicting resource capture, growth, and production in agroforestry systems. Ecol. Eng. 29: 419-433.

World Bank, 2016. Annual report of World Bank. Washington D.C., USA.

World Food Summit, 1996. The times. April 28, Rome, Italy.

Yasmin R, Wadu MA, Mandol MMA and Sharif MO, 2010. Tree diversity in the homestead and cropland areas of Madhupur Upazila under Tangail District. J. Agroforest. Environ. 4: 89-92.

\section{Contribution of Authors}

Amin MHA: Conceived idea, designed research methodology, data collection, data analysis and manuscript writing

Sumi S: Data collection and manuscript write up Jutidamrongphan W: Designed research methodology, manuscript final reading and approval

Techato K: Conceived and designed the research, editing manuscript, statistical analysis and secured funding 